\title{
Pengaruh Pertumbuhan Ekonomi, Investasi Dan Upah Minimum Terhadap Tingkat Pengangguran Di Provinsi Maluku Utara
}

\author{
Yetty $^{1}$, Resmiyati Ansar ${ }^{2}$ \\ ${ }^{1}$ Program Studi Ekonomi Pembangunan, Universitas Khairun \\ ${ }^{2}$ Program Studi Akuntansi, Universitas Khairun
}

Received: Desember 2018; Accepted: Januari 2019; Published: Maret 2019

\begin{abstract}
Abstrak
Studi ini menganalisis faktor-faktor yang mempengaruhi pengangguran di Maluku Utara. Variabel yang digunakan dalam penelitian ini yaitu jumlah pengangguran, pertumbuhan ekonomi, investasi dan upah minimum daerah. Data dianalisis secara kuantitatif dengan menggunakan metode statistik linear berganda. Hasil menunjukkan bahwa pertumbuhan ekonomi dan upah minimum berpengaruh signifikan terhadap pengangguran di Provinsi Maluku Utara. Sedangkan Investasi tidak berpengaruh dan signifikan terhadap pengangguran di Provinsi Maluku Utara. Hal ini disebabkan karena masih tingginya ketergantungan Maluku Utara terhadap pasokan dari luar provinsi menyebabkan terjadinya impor netto antar daerah sehingga menjadi pangsa negatif bagi struktur perekonomian Maluku Utara.
\end{abstract}

Kata kunci: pengangguran, pertumbuhan ekonomi, investasi, upah minimum

\begin{abstract}
The study analyses the determinants of unemployment in North Maluku". The study using such variables as unemployment, economic growth, investment, and local minimum wage. The data analyzed quantitatively by conducting the statistical method of multiple linear regression. The results show that the economic growth and the minimum wages have a significant effect, otherwise the investment has not significant effect on an unemployment in North Maluku Province. This is caused by the high dependence of North Maluku on supplies from outside the province that led to net imports between regions, and it then induce a negative share for the economic structure of North Maluku.
\end{abstract}

Keywords: unemployment, economic growth, investment, minimum wages

How to Cite: Yetty, Ansar, R. (2019). Pengaruh Pertumbuhan Ekonomi, Investasi dan Upah Minimum Terhadap Tingkat Pengangguran Di Provinsi Maluku Utara. JFRES: Journal of Fiscal and Regional Economy Studies, 2 (1), $34-47$. 


\section{PENDAHULUAN}

\section{Latar Belakang}

Pengangguran merupakan masalah yang sangat kompleks karena mempengaruhi sekaligus dipengaruhi oleh beberapa faktor yang saling berinteraksi mengikuti pola yang tidak selalu mudah dipahami dan sampai saat ini belum bisa untuk diatasi oleh pemerintah nasional pada umumnya dan pemerintah daerah pada khususnya. Besarnya angka pengangguran terbuka mempunyai implikasi sosial yang luas, karena mereka yang tidak bekerja berarti tidak mempunyai penghasilan. Persoalannya semakin rumit karena semakin tinggi angka pengangguran terbuka maka semakin besar potensi kerawanan sosial yang mungkin ditimbulkannya, contohnya menimbulkan kerawanan berbagai kriminal dan gejolak sosial, politik, kemiskinan dan pemborosan yang luar biasa (BPS, 2007).

Secara umum jumlah pengangguran terbuka di Provinsi Maluku Utara selama tahun 2011-2016 mengalami fluktuasi. Peningkatan yang tajam terlihat terjadi pada tahun 2015 sebesar 31.058 jiwa. Namun, pada tahun-tahun tertentu jumlah pengangguran di Provinsi Maluku Utara juga mengalami penurunan. Tingkat pengangguran terbuka di Maluku Utara pada tahun 2016 sebesar $4,01 \%$, angka ini turun dibanding tahun sebelumnya yaitu sebesar $6,05 \%$, ini artinya jumlah pengangguran menurun. Berkat kinerja sektor pertanian yang membaik, peningkatan jumlah pengangguran tersebut masih lebih rendah dibandingkan tahun sebelumnya. Dengan perkembangan tersebut, Tingkat Pengangguran Terbuka turun dari $6,05 \%$ menjadi $4,01 \%$ (BPS Maluku Utara, 2017).

Pertumbuhan ekonomi di Provinsi Maluku Utara mengalami pertumbuhan yang melambat. Pertumbuhan ekonomi Maluku Utara pada tahun 2010 tumbuh cukup besar mencapai 7,95\%. Selanjutnya pada tahun 2013 tumbuh melambat $6,36 \%$. Dilihat dari sisi penawaran (lapangan usaha), perekonomian Maluku Utara ditopang oleh sektor perdagangan, hotel dan restoran (PHR) serta sektor pertanian, khususnya pada subsektor perkebunan. Kenaikan harga komoditas perkebunan pada akhir tahun 2010 merupakan salah satu faktor pendorong kinerja sektor ini. Kenaikan harga komoditas perkebunan telah mendorong petani untuk meningkatkan produksinya sehingga akhir tahun 2010 sektor pertanian tumbuh sebesar 6,74\% dengan kontribusi pada PDRB sebesar 2,32\% (Maluku Utara Dalam Angka, 2010).

Variabel lain yang juga berpengaruh terhadap tingkat pengangguran melalui pertumbuhan ekonomi adalah akumulasi modal yang secara akumulatif memiliki nilai investasi dan output atau produksi yang lebih besar dan selanjutnya dapat mendorong meningkatnya pendapatan masyarakat. Hal inilah yang memacu pemerintah daerah untuk meningkatkan pertumbuhan ekonominya melalui suntikan modal berupa investasi baik yang dilakukan oleh PMA maupun PMDN (Priambodo, 2014).

Investasi di Maluku Utara meskipun masih tumbuh secara positif, namun pertumbuhannya mengalami perlambatan. Meskipun sempat mengalami peningkatan di akhir tahun 2009 sebesar 23,6\%., namun pada awal tahun 2010 kinerjanya kembali melambat sebesar 4,2\%. Masih positifnya kinerja ekspor didukung pula oleh perkembangan kredit investasi yang masih bergerak positif. Belum adanya investasi baru, ditambah dengan relatif lambatnya realisasi belanja pemerintah untuk pembangunan infrastruktur, merupakan faktor utama turunnya investasi. Beberapa proyek yang mengalami gangguan diantaranya proyek jalan DarubaWayabula dan Proyek pembangunan terminal Bandara Babullah (KER Malut, 2010).

Upah juga merupakan salah satu faktor yang berpengaruh terhadap tingkat pengangguran suatu daerah, karena rendahnya tingkat upah dapat pula menjadi masalah ketenagakerjaan di Provinsi Maluku Utara. secara keseluruhan tingkat upah minimum di Provinsi Maluku Utara meningkat setiap tahunnya. Upah Minimum tertinggi tahun 2016 yaitu sebesar Rp 1.975.152 pada tahun 2011 dan tingkat upah terendah yaitu sebesar Rp 847.000. Apabila ditinjau dari sisi pengusaha, meningkatnya upah akan meningkatkan biaya yang dikeluarkan oleh perusahaan, maka akan mengurangi efisiensi pengeluaran,sehingga pengusaha akan mengambil kebijakan pengurangan tenaga kerja guna mengurangi biaya produksi. Hal ini akan berakibat pada peningkatan pengangguran (Sopianti, 2013).

Berdasarkan penjelasan latar belakang, penulis dapat menyimpulkan bahwa pertumbuhan ekonomi Maluku Utara dari tahun ke tahun terus mengalami peningkatan, akan tetapi di sisi lain peningkatan ini justru tidak dapat menyerap banyak tenaga kerja. Selama kurun waktu tahun 2008 hingga 2013 pertumbuhan ekonomi Maluku Utara selalu berada diatas pertumbuhan 
ekonomi nasional, akan tetapi tingkat pengangguran terbuka di Maluku Utara tergolong fluktuatif. Bila dilihat nilai investasi tumbuh melambat, jika investasi tanpa diikuti dengan penyediaan lapangan kerja akan mengakibatkan jumlah pengangguran semakin bertambah. Selain itu, semakin tinggi tingkat upah yang ditetapkan, maka berpengaruh pada meningkatnya biaya produksi, akibatnya untuk melakukan efisiensi, perusahaan terpaksa melakukan pengurangan tenaga kerja, yang berakibat pada tingginya pengangguran.

Tujuan dari penelitian ini adalah menganalisis pengaruh pertumbuhan ekonomi, investasi dan upah minimum terhadap tingkat pengangguran di Provinsi Maluku Utara. Hasil penelitian ini diharapkan menjadi masukan yang berguna untuk penulisan selanjutnya serta berguna khususnya untuk pemerintah dalam memperhatikan masalah pengangguran terutama di Provinsi Maluku Utara. Pemerintah perlu membangun suatu sistem yang mengelola seluruh informasi pasar kerja, bisa menciptakan investasi yang sehat serta mampu meningkatkan produktivitas tenaga kerja agar dapat sebanding dengan kenaikan tingkat upah yang ditentukan dalam upah minimum.

\section{TINJAUAN PUSTAKA}

\section{Pengangguran}

Pengangguran adalah jumlah tenaga kerja dalam perekonomian yang secara aktif mencari pekerjaan tetapi belum memperolehnya (Sukirno, 2004)

Selanjutnya International Labor Organization (ILO) memberikan definisi pengangguran yaitu:

1. Pengangguran terbuka adalah seseorang yang termasuk kelompok penduduk usia kerja yang selama periode tertentu tidak bekerja, dan bersedia menerima pekerjaan, serta sedang mencari pekerjaan.

2. Setengah pengangguran terpaksa adalah seseorang yang bekerja sebagai buruh karyawan dan pekerja mandiri (berusaha sendiri) yang selama periode tertentu secara terpaksa bekerja kurang dari jam kerja normal, yang masih mencari pekerjaan lain atau masih bersedia mencari pekerjaan lain/tambahan (BPS, 2001).

\section{Faktor Penyebab Pengangguran di Negara Berkembang}

Ada beberapa faktor yang menjadi penyebab pengangguran di negara-negara berkembang, antara lain: a. Kebijakan Pemerintah yang Tidak Tepat

Perekonomian di negara berkembang pada umumnya dikategorikan ke dalam dua sektor, yaitu sektor subsisten yang diasumsikan dan dicirikan sebagai sektor yang lamban, tradisional, terbelakang, dan mempunyai pengangguran tidak kentara dan sektor modern berupa pertambangan, perkebunan, dan industri. Pada akhirnya pembangunan disusun dengan strategi perluasan sektor modern melalui akumulasi kapital. Dimana pertumbuhan sektor modern akan menyerap angkatan kerja dari sektor tradisional sampai pada akhirnya tidak ada lagi yang tersisa. Namun, pada kenyataannya, tidak semua negara berkembang dapat mengikuti perkembangan dan kemajuan industri. Yang berakibat kepada meningkatnya penggunaan teknologi yang padat kapital, sehingga mendorong meningkatnya investasi.

b. Tingginya Upah di Sektor Modern

Upah yang berlaku untuk tenaga kerja tak berskill di sektor modern di negara-negara berkembang seringkali melebihi tingkat upah keseimbangan pasar karena adanya kebijakan upah minimum dari pemerintah, tekanan serikat pekerja, dan perusahaan asing yang beroperasi di negara tersebut yang biasanya menentukan upah lebih tinggi dari tingkat upah domestik. Pemerintah sering berinisiatif memberlakukan kebijakan upah minimum dengan argumentasi untuk membantu para pekerja miskin. Sementara itu, perusahaan asing yang berlokasi di negara tersebut biasanya memberikan upah yang meskipun di bawah standar negara mereka, tetapi lebih tinggi dari standar domestik untuk memastikan mendapatkan tenaga kerja berkualitas dan akhirnya mendorong tingkat upah domestik untuk ikut meningkat. Jika dihitung secara kasar di seluruh negara berkembang, Pendapatan per pekerja dari upah minimum resmi ternyata beberapa kali lebih tinggi daripada pendapatan per kapita negara tersebut Hal ini akan menyebabkan pengangguran yang lebih tinggi karena beberapa studi menunjukkan tingkat upah yang tinggi akan mengurangi penyerapan tenaga kerja.

c. Rendahnya Biaya Kapital

Beberapa kebijakan pemerintah telah membuat biaya kapital di negara-negara berkembang menjadi rendah, misalnya kebijakan mendorong investasi dengan mengenakan subsidi tingkat bunga dan 
potongan pajak, atau kebijkan menjaga tingkat kurs lebih rendah dari keseimbangan pasar. Kurs yang rendah membuat harga barang impor, termasuk barang-barang kapital menjadi murah. Kebijakan ini ditunjang pula dengan kebijakan pemerintah di negara berkembang untuk memprioritaskan impor barang-barang kapital dan megadopsi teknologi padat kapital yang akan menyerap sedikit tenaga kerja.

\section{Pertumbuhan Ekonomi}

Pertumbuhan Ekonomi adalah kenaikan output perkapita dalam jangka panjang. Tekanannya adalah pada tiga aspek, yaitu proses, output perkapita dan jangka panjang. Pertumbuhan Ekonomi adalah suatu "proses", bukan gambaran sesaat (Sukirno, 2006). Pertumbuhan ekonomi merupakan suatu keadaan sistem perekonomian yang ada di negara, suatu negara bisa mengukur baik tidaknya perekonomian bisa diukur melalui pertumbuhan ekonomi jika pertumbuhan ekonomi di suatu negara kecil maka pemerintah harus melakukan kebijakan ekonomi guna menaikan angka petumbuhan ekonomi di negaranya, dan jika pertumbuhan ekonomi tinggi maka pemerintah harus mempertahankan bahkan menaikannya lebih tinggi pertumbuhan dan pembangunan ekonominya.

Arthur Okun (1929-1979) adalah salah seorang pembuat kebijakan paling kreatif pada era sehabis perang. Ia membuat konsep output potensial dan menunjukkan hubungan antara output dan pengangguran. Pengangguran biasanya bergerak bersamaan dengan output pada siklus bisnis. Pergerakan bersama dari output dan pengangguran yang luar biasa ini berbarengan dengan hubungan numerikal yang sekarang dikenal dengan nama Hukum Okun. Hubungan antara tingkat GDP yang berpengaruh terhadap tingkat pengangguran didasarkan pada hukum Okun (Okun's Law ) yang menguji hubungan antara tingkat pengangguran dengan tingkat GDP suatu Negara. Hukum Okun menyatakan bahwa untuk setiap penurunan 2 persen GDP yang berhubungan dengan GDP potensial, maka angka pengangguran meningkat sekitar 1 persen. Hukum Okun menyediakan hubungan yang sangat penting antara pasar output dan pasar tenaga kerja. Pada siklus bisnis, pengangguran bergerak bersamaan dengan output. Agar pengangguran tidak meningkat maka GDP harus ditingkatkan setinggi-tingginya (Samuelson, 2004).

\section{Hubungan antara Pertumbuhan Ekonomi dengan Pengangguran}

Pertumbuhan ekonomi dan pengangguran merupakan salah satu isu yang paling diperbincangkan dan sangat berkaitan satu sama lain. Menurut Herman (2011), Pertumbuhan ekonomi yang tinggi dapat menghasilkan lapangan kerja baru sehingga mampu menjamin pentingnya kondisi ekonomi dan pembangunan didalam suatu daerah sehingga pemerintah dalam hal ini perlu melakukan tindakan dalam meningkatkan intensitas pertumbuhan ekonomi agar tingkat pengangguran berkurang. Pertumbuhan ekonomi berkaitan erat dengan proses peningkatan produksi barang dan jasa dalam kegiatan ekonomi masyarakat (Dewi, 2013).

Secara teori setiap adanya peningkatan dalam pertumbuhan ekonomi Indonesia diharapkan dapat menyerap tenaga kerja, sehingga dapat mengurangi jumlah pengangguran. Pertumbuhan ekonomi di Indonesia dapat diukur melalui peningkatan atau penurunan GDP yang dihasilkan suatu negara, karena indikator yang berhubungan dengan jumlah pengangguran adalah GDP.

Tinggi/rendahnya tingkat pengangguran suatu negara dapat dikaitkan dengan pertumbuhan GDP dalam negara tersebut atau untuk skala yang lebih kecil lingkupnya disebut Produk Domestik Regional Bruto (PDRB), yang berarti peningkatan pendapatan daerah. Hukum Okun (Okun's law) menjelaskan adanya hubungan yang negatif antara pengangguran dengan PDRB. Bahwa setiap peningkatan pengangguran cenderung dikaitkan dengan menurunnya pertumbuhan ekonomi, sehingga, ketika pertumbuhan ekonomi menurun, maka jumlah pengangguran akan cenderung meningkat, Sebaliknya, apabila pertumbuhan ekonomi mengalami peningkatan, maka masalah pengangguran dapat berkurang (Samuelson, 2004).

\section{Teori Investasi}

Investasi dapat diartikan sebagai pengeluaran atau pembelanjaan penanam-penanam modal atau perusahaan untuk membeli barang-barang modal dan perlengkapan produksi untuk menambah kemampuan memproduksi barangbarang dan jasa-jasa yang tersedia dalam perekonomian (Sukirno, 2001). Menurut Suparmoko (1993) memberikan arti investasi sebagai pengeluaran atau pembelanjaan 
penanam-penanam modal dan perlengkapan produksi untuk menambah kemampuan memproduksi barang-barang dan jasa-jasa yang tersedia dalam perekonomian. Investasi sangat berperan penting didalam pembangunan ekonomi suatu daerah dimana investasi asing dapat mempercepat laju pertumbuhan ekonomi. Sementara itu, tingkat pengangguran suatu daerah dapat dilihat melalui kenaikan pertumbuhan ekonomi suatu daerah. Semakin tinggi pertumbuhan ekonomi suatu daerah, maka semakin tinggi tingkat kesejahteraan masyarakatnya dan tingkat pengangguran semakin menurun.

\section{Hubungan Investasi dengan Pengangguran}

Besar kecilnya investasi yang terjadi di masyarakat akan sangat mempengaruhi besar kecilnya kesempatan kerja yang tercipta dalam masyarakat tersebut. Adanya investasi akan meningkatkan kegiatan produksi sehingga akan membuka kesempatan kerja baru. Adanya kesempatan kerja baru akan menyebabkan berkurangnya jumlah pengangguran. Jadi, antara investasi dan pengangguran terdapat hubungan negatif. Ini berarti jika tingkat investasi naik maka tingkat pengangguran akan turun. Tapi apabila investasi turun, maka tingkat pengangguran akan meningkat. Namun apabila investasi yang ditanamkan bersifat padat modal, maka kenaikan investasi tidak berpengaruh terhadap pasar tenaga kerja.

Hubungan antara investasi (PMA dan PMDN) dengan kesempatan kerja menurut HarrodDomar (Mulyadi, 2000), investasi tidak hanya menciptakan permintaan, tetapi juga memperbesar kapasitas produksi. Artinya, semakin besar kapasitas produksi akan membutuhkan tenaga kerja yang semakin besar pula, dengan asumsi "full employment". Ini karena investasi merupakan penambahan faktorfaktor produksi, yang mana salah satu dari faktor produksi adalah tenaga kerja. Dengan begitu, perekonomian secara keseluruhan dapat menyerap tenaga kerja sebanyak - banyaknya, sehingga partisipasi angkatan kerja akan semakin meningkat pula.

Dinamika penanaman modal mempengaruhi tinggi rendahnya pertumbuhan ekonomi, mencerminkan marak lesunya pembangunan. Maka setiap Negara berusaha menciptakan iklim yang dapat menggairahkan investasi terutama investasi swasta yang dapat membantu membuka lapangan kerja sehingga dapat meningkatkan kesempatan kerja dan mengurangi tingkat pengangguran (Dumairy, 1997).

\section{Upah}

Salah satu faktor produksi yang berpengaruh dalam kegiatan produksi adalah upah tenaga kerja. Tenaga kerja dapat membantu dalam proses produksi sehingga menghasilkan output yang diinginkan perusahaan. Adanya pengorbanan yang dikeluarkan tenaga kerja untuk perusahaan maka tenaga kerja berhak atas balas jasa yang diberikan perusahaan kepada tenaga kerja tersebut berupa upah.

Pengertian upah menurut Undang-undang Republik Indonesia No. 13 tahun 2003 tentang Jaminan Sosial Tenaga Kerja pasal 88 butir 3 menjelaskan bahwa upah adalah suatu penerimaan atau imbalan dari pengusaha keppada tenaga kerja untuk suatu pekerjaan yang telah dilakukan, dan uapah tersebut dinyatakan atau dinilai dalam bentuk suatu perjanjian.

Dalam hal ini upah yang diberikan kepada tenaga kerja yang sudah memberikan produktivitasnya kepada perusahaan sesuai dengan ketentuan atau kesepakatan yang sudah berlaku antara pekerja dengan pengusaha. Upah yang biasanya diterima oleh tenaga kerja selama ini adalah upah yang sudah ditetapkan oleh pemerintah daerah provinsi, yang dikenal dengan istilah Upah Minimum Provinsi (UMP), yang hanya bisa memenuhi Kebutuhan Hidup Minimum (KMH) pekerja.

Sadono Sukirno (2008) membuat perbedaan diantara dua pengertian upah :

1. Upah nominal (upah uang) adalah jumlah uang yang diterima para pekerja dari para pengusaha sebagai pembayaran atas tenaga mental dan fisik para pekerja yang digunakan dalam proses produksi.

2. Upah riil adalah tingkat upah pekerja yang diukur dari sudut kemampuan upah tersebut membeli barang-barang dan jasa-jasa yang diperlukan untuk memenuhi kebutuhan para pekerja.

\section{Hubungan Besaran Upah dengan Pengangguran}

Kebijakan lainnya yang sering ditempuh oleh pemerintah untuk menekan tingkat pengangguran yaitu dengan kebijakan penetapan upah minimum. Upah Minimum sebagaimana yang dikemukakan didalam teori upah efisiensi bertujuan untuk meningkatkan produktivitas dari tenaga kerja, sehingga berdampak pada meningkatnya hasil produksi 
dari suatu perusahaan, kemudian akan diikuti dengan meningkatnya permintaan akan tenaga kerja. Teori upah efisiensi ini juga didukung oleh hasil penelitian yang dilakukan oleh Nababan, 2017; Putri \& Sasana, 2017 yang mengatakan bahwa upah minimum dapat meningkatkan kesempatan kerja. Pandangan teori upah efisiensi ini juga berbeda dengan teori upah sebelumnya yang menganggap upah sebagai sebagai suatu biaya produksi,dan apabila terjadi kenaikan tingkat upah akan berdampak pada menurunnya permintaan akan tenaga kerja. Hubungan besaran upah yang berpengaruh terhadap jumlah pengangguran dijelaskan oleh Kaufman dan Hotckiss (1999). Tenaga kerja yang menetapkan tingkat upah minimumnya pada tingkat upah tertentu, jika seluruh upah yang ditawarkan besarnya dibawah tingkat upah tersebut, seseorang akan menolak mendapatkan upah tersebut dan akibatnya menyebabkan pengangguran. Jika upah yang ditetapkan pada suatu daerah terlalu rendah, maka akan berakibat pada tingginya jumlah pengangguran yang terjadi pada daerah tersebut. Namun dari sisi pengusaha, jika upah meningkat dan biaya yang dikeluarkan cukup tinggi, maka akan mengurangi efisiensi pengeluaran, sehingga pengusaha akan mengambil kebijakan pengurangan tenaga kerja guna mengurangi biaya produksi. Hal ini akan berakibat peningkatan pengangguran.

\section{METODE PENELITIAN}

Jenis data yang digunakan dalam penelitian ini adalah yang bersifat kuantitatif yaitu data yang berbentuk angka-angka. Sedangkan sumber data yang digunakan dalam penelitian ini adalah sumber data sekunder yang diperoleh dari Badan Pusat Statistik Provinsi Maluku Utara pada kurun waktu 2011-2016.

Model analisis yang digunakan dimulai dengan pembentukan model matematis, yaitu suatu pernyataan hubungan yang berlaku di antara pertumbuhan ekonomi dan investasi terhadap tingkat pengangguran di Maluku Utara.

Adapun model persamaannya adalah sebagai berikut:

$$
Y=f(X 1, X 2, X 3)
$$

Kemudian dispesifikasi dalam model distributed lag dengan persamaan regresi linear berganda, yaitu sebagai berikut:

$$
U_{n}=\alpha-\beta_{1} G r-\beta_{2} I n v+\beta_{3} W g+\mu t
$$

Keterangan :

$$
\begin{aligned}
& \mathrm{U}=\text { = Pengangguran (orang) } \\
& \alpha \quad=\text { Intercept } \\
& \mathrm{Gr}=\text { Pertumbuhan ekonomi }(\mathrm{Rp}) \\
& \text { Inv } \quad=\text { Investasi }(\mathrm{Rp}) \\
& \mathrm{Wg} \quad=\text { Upah minimum } \\
& \beta 1, \beta 2, \beta 3=\text { Koefisien Regresi } \\
& \mu \mathrm{t}=\text { Error Term }
\end{aligned}
$$

\section{Test of Goodness of Fit (Uji Kesesuaian)}

Penelitian ini menguji hipotesis-hipotesis dengan menggunakan Metode Analisis Regresi Berganda (Multiple Regression). Metode Regresi Berganda menghubungkan satu variable dependen dengan beberapa variable independen dalam suatu model prediktif tunggal. Adapun untuk menguji signifikan tidaknya hipotesis tersebut digunakan Uji f, Uji t dan koefisien determinan.

\section{Uji Koefisien Determinasi ( $R$-Squared)}

Koefisien determinasi ( $R$-Square) dilakukan untuk melihat seberapa besar kemampuan variabel independen member penjelasan terhadap variable dependen. Nilai $\mathrm{R}^{2}$ berkisar antara 0 sampai $1(0<\mathrm{R} 2<1)$.

\section{Uji F-Statistik (Uji Keseluruhan)}

Uji F-Statistik ini dilakukan untuk melihat seberapa besar pengaruh variabel independen secara bersama-sama terhadap variabel dependen. Untuk pengujian ini digunakan hipotesa sebagi berikut :

- $\mathrm{H} 0: \beta 1=\beta 2=0$

Ho diterima (F-hitung < F-tabel), artinya variabel independen secara bersama-sama tidak berpengaruh nyata terhadap variabel dependen.

- $\mathrm{Ha}: \beta 1 \neq \beta 2 \neq 0$

Ha diterima (F-hitung > F-tabel), artinya variabel independen secara bersama-sama berpengaruh nyata terhadap variabel dependen.

\section{Uji t-statistik}

Uji t merupakan suatu pengujian yang bertujuan untuk mengetahui apakah masing-masing koefisien regresi berpengaruh signifikan atau tidak terhadap variabel dependen dengan menganggap variabel independen lainnya konstan. Dalam hal ini digunakan hipotesis sebagai berikut:

- $\quad \mathrm{H} 0: \beta \mathrm{i}=\beta$ : Ho diterima (t-hitung < $\mathrm{t}$-tabel) artinya variabel independen secara parsial tidak berpengaruh nyata terhadap variabel dependen. 
- $\quad \mathrm{Ha}: \beta \mathrm{i} \neq \beta$ : Ha diterima (t-hitung $>\mathrm{t}$-table) variabel independen secara parsial berpengaruh nyata terhadap variabel independen.

\section{Uji Penyimpangan Asumsi Klasik}

\section{Multikolineritas}

Multikolinieritas adalah alat untuk mengetahui suatu kondisi, apakah terdapat korelasi variabel independen di antara satu sama lainnya. Untuk mengetahui ada tidaknya Multikolinieritas dapat dilihat dari nilai R-Square, F- hitung, t-hitung, serta standart eror. Menurut (Imam Ghozali : 2009) uji multikoliearitas bertujuan untuk menguji apakah model regresi ditemukan adanya korelasi antar variabel bebas (independen). Model regresi yang baik seharusnya tidak terjadi korelasi diantara variabel independen. Jika variabel independen saling berkolerasi, maka variabel-variabel ini tidak ortogonal. Variabel ortogonal adalah variabel independen yang nilai korelasi antar sesama variabel independen sama dengan nol. Untuk mendeteksi ada atau tidaknya multikolinearitas dalam model regresi adalah sebagai berikut :

a. Nilai $\mathrm{R}^{2}$ dalam hasil estimasi regresi tinggi, tetapi secara individual variabel-variabel indipenden banyak yang tidak signifikan mempengaruhi variabel dependen.

b. Selain itu jika dilihat dari matriks korelasi antar variabel-variabel indipenden terdapat korelasi yang cukup tinggi ( umumnya diatas $0,90)$.

c. Standart error tidak terhingga

d. Tidak ada satupun t-statistik yang signifikan pada $\alpha=5 \%, \alpha=10 \%, \alpha=1 \%$.

\section{Autokorelasi}

Autokorelasi terjadi bila error term $(\mu)$ dari waktu yang berbeda berkorelasi. Dikatakan bahwa error term berkorelasi atau mengalami korelasi serial apabila variabel $(\varepsilon i . \varepsilon j) \neq 0$; untuk $\mathrm{i} \neq \mathrm{j}$, dalam hal ini dikatakan memiliki masalah autokorelasi. Untuk mengetahui keberadaan autokorelasi dapat digunakan Lagrange Multiplier Test (LM Test).

Untuk mendeteksi ada atau tidaknya autokorelasi digunakan untuk uji Durbin -Watson dimana hipotesis yang akan diuji adalah:

H0 : tidak ada autokorelasi $(r=0)$

Ha : ada autokorelasi $(r \neq 0)$

Bila nilai DW terletak antara batas atas atau upper bound (du) dan (4-du), maka koefisien atau korelasi sama dengan nol, berarti tidak ada korelasi.

\section{Uji Normalitas}

Uji normalitas bertujuan untuk menguji apakah dalam model regresi variabel dependen, independen atau keduanya terdistribusi normal atau tidak. Model regresi yang baik adalah distribusi data normal atau mendekati normal. Menurut (Imam Ghozali : 2009) ada beberapa cara mendeteksi normalitas dengan melihat penyebaran data (titik) pada sumbu diagonal dari grafik. Dasar pengambilan keputusan dalam uji normalitas adalah :

a. Jika data menyebar disekitar garis diagonal dan mengikuti garis diagonal, maka model regresi memenuhi asumsi normalitas.

b. Jika data menyebar dari garis diagonal dan atau mengikuti arah garis diagonal, maka model regresi tidak memenuhi asumsi normalitas.

\section{HASIL DAN PEMBAHASAN}

\section{Pengujian Kriteria Ekonomi (Uji Koefisien)}

Berdasarkan hasil perhitungan pada lampiran maka dapat ditulis bentuk regresi linier berganda dari model analisis tingkat pengangguran di Provinsi Maluku Utara adalah sebagai berikut:

$$
\begin{gathered}
\mathrm{U}_{\mathrm{n}}=78096,43-0,039 \mathrm{Gr}-0,117 \mathrm{Inv} \\
+0,037 \mathrm{Wg}+\mu \mathrm{t}
\end{gathered}
$$

Persamaan di atas memberikan makna bahwa jika variabel investasi, upah minimum, dan pertumbuhan ekonomi konstan (ceteris paribus) maka tingkat pengangguran sebanyak 78.096 orang. Kemudian perubahan atau kenaikan dalam pertumbuhan ekonomi sebesar Rp.1000 (ceteris paribus) maka akan menurunkan pengangguran sebanyak 39 orang. Setiap perubahan atau kenaikan pada investasi besar Rp.1000 (ceteris paribus) maka akan menurunkan pengangguran sebanyak 117 orang. Serta setiap perubahan atau kenaikan pada upah besar Rp.1000 (ceteris paribus) maka akan menaikan pengangguran sebanyak 37 orang.

\section{Pengujian Koefisien Regresi Secara Parsial (Uji t)}

Pengujian koefisien regresi secara parsial merupakan pengujian terhadap hubungan diantara variabel penelitian secara terpisah. Berdasarkan lampiran dapat ditentukan pengaruhnya terhadap hipotesis yang telah diajukan sebagai berikut: 


\section{Uji Hipotesis 1}

Pertumbuhan ekonomi mempunyai pengaruh negatif terhadap pengangguran di Provinsi Maluku Utara periode 2011 - 2016. Berdasarkan tabel di atas hasil koefisien regresi dari pertumbuhan ekonomi adalah arah negatif sebesar - 0,039 dan nilai t-statistik sebesar 4,753 dengan probabilitas sebesar 0,000 . Nilai signifikansi lebih kecil dari tingkat signifikansi yang digunakan $(0,00<0,05)$, hal ini berarti bahwa variabel pertumbuhan ekonomi berpengaruh negatif dan signifikan terhadap pengangguran di Provinsi Maluku Utara. Jadi dapat disimpulkan dalam penelitian ini hipotesis pertama diterima.

Hal ini berarti bahwa pertumbuhan sektor-sektor ekonomi mampu menyediakan potensi lapangan pekerjaan yang cukup banyak dimasa yang akan datang sehingga mampu mengurangi tingkat pengangguran. Hasil penelitian ini sesuai dengan teori dari hukum okun yang menyatakan bahwa terdapat hubungan negative antara pertumbuhan ekonomi dengan jumlah pengangguran dan juga sesuai dengan yang dinyatakan oleh Arsyad (1999) bahwa pertumbuhan ekonomi secara langsung dan tidak langsung dapat menciptakan lapangan pekerjaan. Hal ini sejalan dengan penelitian yang dilakukan oleh Yeny Dharmayanti (2011) dimana tujuan penelitian ini adalah untuk menganalisis nilai PDRB, Upah dan Inflasi secara individu terhadap tingkat Pengangguran Terbuka di Provinsi Jawa Tengah tahun 1991 - 2009. Dan menganalisis nilai PDRB, Upah dan Inflasi secara bersama - sama terhadap tingkat Pengangguran Terbuka di Provinsi Jawa Tengah Tahun 1991 -2009. Hasil penelitiannya menunjukkan pengaruh PDRB terhadap pengangguran diperoleh nilai $\mathrm{t}$ sebesar -2,164 dengan signifikansi sebesar $0,047<0,05$, dengan demikian diperoleh $t$ hitung $(-2,164)<-1,753$. Hal ini berarti bahwa PDRB memiliki pengaruh negatif yang signifikan terhadap pengangguran.

\section{Uji Hipotesis 2}

Berdasarkan hasil pengujian menunjukkan bahwa secara parsial variabel investasi tidak berpengaruh signifikan terhadap pengangguran di Provinsi Maluku Utara, ini ditunjukkan oleh hasil koefisien regresi dari investasi adalah arah negatif sebesar - 0,117 dan nilai t-statistik sebesar -1,408 dengan probabilitas sebesar 0,174 . Nilai signifikansi lebih besar dari tingkat signifikansi yang digunakan $(0,174>0,05)$, hal ini berarti bahwa variabel investasi tidak berpengaruh dan tidak signifikan terhadap pengangguran di Provinsi Maluku Utara. Jadi dapat disimpulkan dalam penelitian ini hipotesis kedua ditolak.

Hal ini sejalan dengan penelitian yang dilakukan oleh Izhartati (2017), dimana secara parsial investasi dan upah minimum tidak berpengaruh signifikan terhadap penyerapan tenaga kerja di Kota Bandar Lampung. Secars simultan, hasil Uji F menunjukkan bahwa variabel investasi dan upah minimum tidak ada pengaruh secara simultan terhadap penyerapan tenaga kerja di Kota Bandar Lampung. Tidak berpengaruhnya investasi terhadap tingkat pengangguran disebabkan karena investasi di Kota Bandar Lampung lebih banyak disalurkan ke sektor proyek yang padat modal (jasa).

\section{Uji Hipotesis 3}

Berdasarkan hasil pengujian menunjukkan bahwa secara parsial variabel upah minimum mempunyai pengaruh positif terhadap pengangguran di Provinsi Maluku Utara periode 2011 - 2016. Hasil koefisien regresi dari upah minimum adalah arah positif sebesar 0,037 dan nilai t-statistik sebesar -7,032 dengan probabilitas sebesar 0,000 . Nilai signifikansi lebih kecil dari tingkat signifikansi yang digunakan $(0,00<0,05)$, hal ini berarti bahwa variabel upah minimum berpengaruh positif dan signifikan terhadap pengangguran di Provinsi Maluku Utara. Jadi dapat disimpulkan dalam penelitian ini hipotesis ketiga diterima.

Hal ini sejalan dengan penelitian yang dilakukan oleh Ni Wayan Mentari (2013). Teknik analisis data yang digunakan didalam penelitian ini ialah dengan menggunakan tekhnik analisis jalur. Hasil analisis menunjukkan bahwa pertumbuhan ekonomi dan tingkat upah berpengaruh positif dan signifikan terhadap jumlah investasi. Pertumbuhan ekonomi berpengaruh negatif dan signifikan, sedangkan tingkat upah dan jumlah investasi berpengaruh positif dan signifikan terhadap tingkat pengangguran. Pertumbuhan ekonomi dan tingkat upah berpengaruh secara tidak langsung dan signifikan terhadap tingkat pengangguran melalui variabel intervening jumlah investasi. 


\section{Koefisien Determinasi $\left(\mathbf{R}^{2}\right)$}

Untuk melihat kemampuan variabel independent dalam menerangkan atau mengukur besarnya sumbangan terhadap variabel dependen dapat diketahui dari besarnya nilai koefisien determinasi.

Berdasarkan hasil perhitungan pada lampiran menunjukkan bahwa besarnya nilai koefisien determinasi $\mathrm{R}^{2}$ sebesar 0,945 atau $94,50 \%$. Ini berarti bahwa besarnya sumbangan variabel independent (pertumbuhan, investasi dan upah minimum) terhadap variabel dependen (pengangguran) sebesar 94,50\%. Sedangkan sisanya sebesar $5,50 \%$ merupakan variabel atau faktor-faktor yang tidak diteliti.

\section{Hasil Pengujian Asumsi Klasik}

\section{Uji Autokorelasi}

Berdasarkan hasil pengujian menunjukkan bahwa besarnya nilai Durbin-Watson (DWstatistik) sebesar 0,730.Jika dibandingkan dengan tabel pada level kepercayaan 5\%, n-k-1 diperoleh nilai $\mathrm{dL}=1,50$ dan $\mathrm{dU}=0,123$ yang berada diantara nilai $\mathrm{dL}$ dan $\mathrm{dU}(\mathrm{dL}<\mathrm{d}<\mathrm{dU})$. Artinya bahwa pengujian non-otokorelasi tidak dapat disimpulkan. Akan tetapi nilai DurbinWatson di atas masih berada diantara -2 dan +2 yang artinya model regresi tersebut tidak menunjukkan adanya gejala autokorelasi.

\section{Uji Multikolinearitas}

Melihat hasil besaran korelasi antar variabel bebas pada lampiran tampak bahwa tidak ada satu pun variabel yang mempunyai korelasi yang cukup tinggi antar variabel bebas. Hasil perhitungan nilai tolerance juga menunjukkan tidak ada variabel bebas yang memiliki nilai tolerance kurang dari $10 \%$ yang berarti tidak ada korelasi antara variabel bebas yang memiliki nilainya lebih dari $95 \%$. Hasil perhitungan nilai variance inflation factor (VIF) juga menunjukkan hal yang sama, tidak ada satu variabel bebas yang memiliki nilai VIF lebih kecil dari 10. Jadi dapat disimpulkan bahwa tidak ada multikolinearitas antar variabel bebas dalam model regresi.

\section{Uji Normalitas}

Persebaran data tersebar di sekeliling garis lurus pada diagram p-p plot normalitas (tidak terpencar jauh dari garis lurus). Maka dapat dikatakan bahwa persyaratan normalitas bisa dipenuhi dan dapat diindikasikan bahwa data ini memenuhi asumsi normalitas.

\section{Pembahasan}

\section{Pengaruh Pertumbuhan Ekonomi Terhadap Pengangguran}

Pertumbuhan ekonomi merupakan salah satu indikator yang penting dalam menilai kinerja suatu perekonomian. Pertumbuhan ekonomi suatu negara atau suatu wilayah yang terus menunjukkan peningkatan menggambarkan bahwa perekonomian negara atau wilayah tersebut berkembang dengan baik. Sebaliknya apabila suatu perekonomian tersebut tidak dapat berkembang dengan baik hal terburuk yang akan muncul salah satunya adalah masalah pengangguran (Sukirno, 2004).

Pertumbuhan ekonomi Maluku Utara tahun 2017 tumbuh meningkat sebesar $7,31 \%$, jika dilihat dari sisi permintaan, konsumsi rumah tangga masih akan menjadi penggerak utama ekonomi di Provinsi Maluku Utara (Tabel 1). Sementara itu, perbaikan produksi sektor pertanian (termasuk perikanan) dan meningkatnya produksi nikel dan rencana relaksasi UU Minerba berdampak pada peningkatan ekspor baik antar daerah maupun luar negeri. Sedangkan dari sisi penawaran, pertumbuhan ekonomi dipicu dari membaiknya kinerja sektor utama khususnya sektor perdagangan besar dan eceran, sektor pertambangan dan sektor industri pengolahan (KER, Malut, 2017).

Perlambatan pertumbuhan PDRB di Provinsi Maluku Utara tersebut tentunya akan berdampak terhadap penyerapan tenaga kerja dan secara tidak langsung mempengaruhi pada tingkat pengangguran dan begitupun sebaliknya.

Tabel 1. Laju Pertumbuhan PDRB Di Provinsi Maluku Utara

\begin{tabular}{cc}
\hline Tahun & Laju Pertumbuhan PDRB \\
\hline 2010 & $7,95 \%$ \\
2011 & $6,40 \%$ \\
2012 & $6,67 \%$ \\
2013 & $6,36 \%$ \\
2014 & $5,49 \%$ \\
2015 & $6,10 \%$ \\
2016 & $6,54 \%$ \\
2017 & $7,31 \%$ \\
\hline
\end{tabular}

Sumber : BPS Malut, 2017

Kondisi pengangguran di Provinsi Maluku Utara tidak merata, antar satu daerah dengan daerah yang lainnya yang disebabkan oleh kontribusi sektor-sektor unggulan yang berbeda antar masing-masing daerah. Pertumbuhan ekonomi dan pengangguran merupakan salah satu isu yang paling diperbincangkan dan sangat berkaitan satu sama lain. Menurut Herman 
(2011), Pertumbuhan ekonomi yang tinggi dapat menghasilkan lapangan kerja baru sehingga mampu menjamin pentingnya kondisi ekonomi dan pembangunan didalam suatu daerah sehingga pemerintah dalam hal ini perlu melakukan tindakan dalam meningkatkan intensitas pertumbuhan ekonomi agar tingkat pengangguran berkurang.

Beberapa kebijakan yang telah ditempuh oleh pemerintah untuk mengurangi angka pengangguran, salah satunya dengan mendorong pertumbuhan ekonomi agar dapat menciptakan kesempatan kerja (Siregar \& Wahyuniarti, 2008). Hal ini sesuai dengan apa yang dikemukakan oleh Okhun dalam teorinya yang berjudul derive demand theory, yang mengatakan adanya peningkatan permintaan output didalam suatu perusahaan, akan mendorong permintaaan akan tenaga kerja (Juwita, 2014).

Dari hasil penelitian disimpulkan bahwa pertumbuhan ekonomi berpengaruh signifikan terhadap tingkat pengangguran, hal ini sejalan dengan penelitian yang dilakukan oleh Anggun Kembarsari (2010) Dari hasil regresi ditemukan bahwa pertumbuhan ekonomi melalui PDRB signifikan terhadap tingkat pengangguran. Pertumbuhan ekonomi merupakan akibat dari adanya peningkatan kapasitas produksi yang merupakan turunan dari peningkatan investasi. Faktor yang mempengaruhi pertumbuhan ekonomi terhadap pengangguran adalah faktor investasi yang ada dalam industri atau sektor ekonomi lainnya. Dengan meningkatnya investasi, pasti permintaan tenaga kerja akan bertambah, sehingga dengan adanya peningkatan pertumbuhan ekonomi yang diakibatkan oleh adanya peningkatan investasi berpengaruh terhadap penurunan tingkat pengangguran dengan asumsi investasi tidak bersifat padat modal.

Penelitian ini sesuai dengan Hukum Okun yang menjelaskan tentang hubungan negatif pertumbuhan ekonomi dengan pengangguran. Pertumbuhan ekonomi yang terjadi di Maluku Utara pada tahun 2011 sampai dengan 2016 memang telah mengalami kenaikan, akan tetapi kenyatannya pertumbuhan ekonomi ini masih belum dapat dikatakan berhasil.

\section{Pengaruh Investasi Terhadap Pengangguran}

Upaya untuk mendorong investasi, juga merupakan salah satu langkah yang dapat ditempuh didalam menciptakan kesempatan kerja. Secara teoritis, makin besar nilai investasi yang dilakukan atau ditanamkan oleh suatu perusahaan makin besar pula tambahan penggunaan tenaga kerja (Sasongko \& M Suparmoko, 1990).

Pertumbuhan investasi atau modal tetap domestik bruto (PMTB) agak membaik pada 2015 tercatat sebesar 9,67\% dibandingkan dengan tahun sebelumnya. Harga komoditas unggulan Maluku Utara yang terus mengalami penurunan menyebabkan para pelaku usaha cenderung menunda kegiatan investasi barunya.

Tabel 2. Nilai Investasi Provinsi Maluku Utara (Miliar Rupiah)

\begin{tabular}{ccc}
\hline Tahun & Nilai Investasi & Perkembangan \\
\hline 2010 & $3.431,17$ & - \\
2011 & $4.212,40$ & $22,76 \%$ \\
2012 & $4.659,08$ & $10,60 \%$ \\
2013 & $5.026,49$ & $7,88 \%$ \\
2014 & $5.251,23$ & $4,47 \%$ \\
2015 & $5.759,04$ & $9,67 \%$ \\
\hline Total & $28.339,41$ & $55,38 \%$ \\
\hline Rata-rata & $4.723,23$ & $9,23 \%$
\end{tabular}

Sumber : BPS Malut, 2015

Nilai investasi Maluku Utara mengalami perlambatan dengan rata-rata investasi pertahun sebesar 4.723,23 (dalam milyar Rupiah) atau sekitar 9,23\%. Jika dilihat pertumbuhan investasi masih rendah di tahun 2014 hanya tumbuh sebesar 4,47\% (Tabel 2).

Masih tingginya ketergantungan Maluku Utara terhadap pasokan dari luar provinsi menyebabkan terjadinya impor netto antar daerah sehingga menjadi pangsa negatif bagi struktur perekonomian Maluku Utara. Perlambatan ekonomi yang terjadi berpengaruh terhadap ketenagakerjaan di Maluku Utara. Penurunan jumlah tenaga kerja tersebut, mendorong adanya kenaikan angka pengangguran.

Berdasarkan hasil estimasi, investasi tidak memiliki pengaruh terhadap tingkat pengangguran di Provinsi Maluku Utara. Hasil ini berbeda teori ekonomi klasik yang mengatakan bahwa investasi atau pembentuk modal akan mempertinggi alat-alat modal dalam masyarakat. Apabila itu bertambah berarti produksi dan pendapatan nasional akan meningkat,sehinngga akan mendorong pertumbuhan ekonomi, dan terakhir akan meningkatkan kesempatan kerja. Hasil penelitian ini juga berbeda dengan penelitian sebelumnya yang dilakukan oleh Ariani (2013), yang mengatakan bahwa investasi dapat memperluas kesempatan kerja melalui pertumbuhan ekonomi. Faktor yang mengakibatkan investasi 
di Provinsi Sulawesi Selatan belum mampu menciptakan kesempatan kerja melalui pertumbuhan ekonomi yaitu disebabkan karena masih belum meratanya investasi di beberapa daerah di Provinsi Sulawesi Selatan, sehingga berakibat pada pertumbuhan ekonomi yang tinggi dan kesempatan kerja yang luas sangat sulit untuk dicapai.

Penelitian ini tidak sejalan dengan pernyataan dari Todaro (2003) bahwa investasi memainkan peran penting dalam menggerakkan ekonomi karena dengan pembentukan modal dapat membentuk kapasitas produksi maupun menciptakan lapangan kerja baru sehingga dapat memperluas kesempatan kerja. Dengan adanya pembentukan lapangan pekerjaan baru secara tidak langsung investasi mengurangi jumlah pengangguran.

\section{Pengaruh Upah Minimum Terhadap Pengangguran}

Upah juga merupakan salah satu faktor yang berpengaruh terhadap tingkat pengangguran suatu daerah, karena rendahnya tingkat upah dapat pula menjadi masalah ketenagakerjaan di Propinsi Maluku Utara. Penetapan tingkat upah merupakan kewenangan dari pemerintah yang berpengaruh terhadap besarnya tingkat pengangguran di suatu daerah. Semakin tinggi tingkat upah yang ditetapkan oleh pemerintah, maka akan menyebabkan semakin sedikit pula jumlah tenaga kerja yang bekerja (Alghofari, 2009). Penentuan tingkat upah dipengaruhi oleh kondisi perekonomian suatu daerah yang memacu terhadap pertumbuhan ekonomi daerah tersebut. Artinya,semakin baik kondisi perekonomian suatu daerah, maka semakin meningkat pula pertumbuhan ekonomi daerah tersebut sehingga penentuan tingkat upah juga semakin meningkat.

Secara keseluruhan tingkat upah minimum kabupaten/kota di Propinsi Maluku Utara meningkat setiap tahunnya. Upah Minimum tertinggi setiap tahunnya terdapat pada sektor pertambangan dan galian khususnya pertambangan emas yaitu sebesar Rp 3.332.173 dan tingkat upah terendah terdapat pada sektor perkebunan yaitu sebesar Rp 1.992.457. Apabila ditinjau dari sisi pengusaha, meningkatnya upah akan meningkatkan biaya yang dikeluarkan oleh perusahaan, maka akan mengurangi efisiensi pengeluaran, sehingga pengusaha akan mengambil kebijakan pengurangan tenaga kerja guna mengurangi biaya produksi. Hal ini akan berakibat pada peningkatan pengangguran (Sopianti, 2013).

Perkembangan upah minimum regional memiliki tren meningkat dari tahun 2011-2016. Upah minimum regional Maluku Utara memasuki tahun 2013 terjadi peningkatan yang signifikan dari tahun sebelumnya dari 5\% menjadi $35 \%$, dengan rata-rata peningkatan pertahunnya berkisar $10,46 \%$ (Tabel 3). Peningkatan ini didukung oleh kenaikan harga atau inflasi yang tinggi, sehingga pemerintah perlu meningkatkan standar upah yang sesuai dengan tingkat kebutuhan hidup minimum yang layak.

Tabel 3. Upah Minimum Provinsi Maluku Utara (Rupiah)

\begin{tabular}{ccc}
\hline Tahun & Upah Minimum & Perkembangan \\
\hline 2011 & 847.000 & - \\
2012 & 889.350 & $5,00 \%$ \\
2013 & 1.200 .622 & $35,00 \%$ \\
2014 & 1.440 .746 & $19,99 \%$ \\
2015 & 1.681 .266 & $16,69 \%$ \\
2016 & 1.975 .152 & $17,48 \%$ \\
\hline Total & & $94,15 \%$ \\
\hline Rata-rata & & $10,46 \%$ \\
\hline
\end{tabular}

Sumber : BPS Malut, 2016

Dari hasil penelitian dapat disimpulkan bahwa tingkat upah minimum memiliki pengaruh positif terhadap tingkat pengangguran dimana kenaikan tingkat upah akan menyebabkan kenaikan biaya produksi sehingga menyebabkan kenaikan harga produk. Kenaikan harga produk akan mendapat respon negatif dari konsumen sehingga konsumen mengurangi pembelian. Kondisi tersebut menyebabkan produsen mengurangi produksi dan akan berpengaruh terhadap pengurangan jumlah tenaga kerja yang diserap dan pada akhirnya pengangguran akan meningkat. Hasil penelitian ini sesuai dengan penelitian yang dilakukan oleh Indra(2016) menunjukkan bahwa selama tahun 2010 sampai 2012, tingkat pendidikan sarjana, upah, inflasi dan pertumbuhan ekonomi mempunyai pengaruh signifikan terhadap tingkat pengangguran, sedangkan tingkat pendidikan SMA (TPSMA) tidak memiliki pengaruh signifikan terhadap tingkat pengangguran.

Sejalan dengan penelitian yang dilakukan oleh Agustina Mustika (2010) menyatakan bahwa upah signifikan terhadap tingkat pengangguran. Pengaruh nilai koefisien positif yang terjadi antara upah terhadap tingkat pengangguran pada studi kasus 33 Provinsi di Indonesia. Pemerintah harus menyelaraskan antara kebutuhan pokok masyarakat Indonesia dengan pendapatan masyarakat, agar tidak terjadi kesenjangan 
antara pendapatan dan pengeluaran. Dengan cara melakukan evaluasi rata-rata upah per provinsi setiap 3 bulan sekali mengikuti kebutuhan dan standar hidup di 33 provinsi di Indonesia.

Hubungan upah yang berpengaruh terhadap tingkat pengangguran dijelaskan oleh Kaufman dan Hotckiss (1999). Tenaga kerja yang menetapkan tingkat upah minimumnya pada tingkat upah tertentu, jika seluruh upah yang ditawarkan besarnya dibawah tingkat upah tersebut, seseorang akan menolak menerima upah tersebut dan tidak menerima pekerjaan yang ditawarkan, akibatnya menyebabkan pengangguran. Jika upah yang ditetapkan pada suatu daerah lebih rendah dan pada tingkat upah minimalnya, maka akan berakibat pada meningkatnya jumlah pengangguran yang terjadi pada daerah tersebut. Kondisi tersebut akan menyebabkan terjadinya peningkatan pengangguran.

\section{PENUTUP}

\section{Kesimpulan}

Berdasarkan hasil analisis data tentang pengangguran, maka dalam penulisan ini dapat ditarik kesimpulan sebagai berikut:

1. Pertumbuhan ekonomi berpengaruh negatif dan signifikan terhadap pengangguran di Provinsi Maluku Utara. Artinya ketika pertumbuhan ekonomi mengalami kenaikan maka akan menurunkan jumlah pengangguran, dan sebaliknya.

2. Investasi berpengaruh negatif, tetapi tidak signifikan terhadap pengangguran di Provinsi Maluku Utara. Ketika investasi mengalami kenaikan ternyata tidak berdampak pada penurunan jumlah pengangguran. Hal ini disebabkan karena masih tingginya ketergantungan Maluku Utara terhadap pasokan dari luar provinsi menyebabkan terjadinya impor netto antar daerah sehingga menjadi pangsa negatif bagi struktur perekonomian Maluku Utara. Perlambatan ekonomi mempengaruhi ketenagakerjaan di Maluku Utara. Penurunan jumlah tenaga kerja mendorong adanya kenaikan angka pengangguran.

3. Upah minimum berpengaruh positif dan signifikan terhadap tingkat pengangguran di Provinsi Maluku Utara. Artinya kenaikan upah minimum regional tidak selalu berdampak baik terhadap pengurangan jumlah pengangguran. Hal ini disebabkan perusahaan membatasi dalam merekrut tenaga kerja agar mengurangi biaya modal sehingga kenaikan upah secara tidak langsung mengakibatkan bertambahnya jumlah pengangguran.

\section{Saran}

Dari hasil penelitian yang dilakukan dan didasarkan pada kesimpulan diatas, maka saran yang bisa disampaikan diantaranya:

1. Pengangguran yang terjadi tidak hanya disebabkan karena kurangnya lowongan pekerjaan, tetapi juga disebabkan oleh kurangnya keterampilan yang dimiliki oleh pencari kerja serta tingkat upah yang tidak sesuai. Oleh sebab itu sangat diharapkan peran serta pemerintah untuk menanggulangi hal ini dengan mengambil suatu kebijakan atau mungkin bisa memberikan investasi kepada pengusaha-pengusaha UMKM (menggalakkan pengembangan sektor informal, seperti home industry), dengan semakin banyaknya ada UMKM secara tidak langsung lowongan pekerjaan juga bertambah dan hal ini diharapkan agar dapat mengurangi tingkat pengangguran.

2. Pemerintah diharapkan dapat lebih memaksimalkan sektor-sektor yang menjadi sektor unggulan di masing-masing kabupaten/kota di Provinsi Maluku Utara, karena memaksimalkan sektor unggulan pada tiap-tiap daerah pada kabupaten/kota, dapat meningkatkan PDRB daerah tersebut dan secara tidak langsung akan dapat menyerap tenaga kerja sehingga tingkat pengangguran di suatu daerah pada kabupaten/kota di Provinsi Maluku Utara dapat berkurang.

3. Pemerintah daerah hendaknya mendorong investasi pada sektor-sektor yang padat karya dan perlu memperhatikan tumbuhkembangnya industri kecil dan rumah tangga (IKRT), karna IKRT cenderung mampu menyerap banyak tenaga kerja. Kecenderungan menyerap tenaga kerja umumnya membuat IKRT juga insentif dalam dalam menggunakan sumber daya alam lokal, misalnya home industri kerajinan kursi bambu, sehingga pertumbuhan IKRT akan menimbulkan dampak positif terhadap peningkatan jumlah tenaga kerja yang berefek pada penurunan jumlah pengangguran di Maluku Utara.

4. Hendaknya pemerintah daerah menyusun kebijakan pengupahan sedemikian rupa sehingga mampu meningkatkan produktifitas tenaga kerja dan pertumbuhan produksi serta 
meningkatkan penghasilan dan kesejahteraan pekerja. Sehingga kebijakan pengupahan akan berorientasi kepada kepentingan seluruh pihak.

\section{DAFTAR PUSTAKA}

Aditya Barry Kurniawan. (2014). Analisis Pengaruh Pertumbuhan Ekonomi, Upah Minimum, Dan Investasi Terhadap Jumlah Pengangguran Di Kabupaten Gresik. Jurusan Ilmu Ekonomi Fakultas Ekonomi Dan Bisnis Universitas Brawijaya Malang.

Agustina, Mustika. (2010). Analisis tingkat pengangguran dan faktor-faktor yang mempengaruhinya di Kota Semarang .

Alghofari, Farid. (2012). Analisis Tingkat Pengangguran Di Indonesia. http://eprints.undip./26483/2/Jurnal_Skrip si.pdf (22 Feb.2012).

Anggun, Kembar Sari. (2012). Analisis Tingkat Pendidikan, Pertumbuhan Ekonomi, dan Upah Terhadap Pengangguran Terdidik di Sumatera Barat. Jurnal Ekonomi Pembangunan, Universitas Negeri Padang.

Ariani, D. W. (2013). The relationship between employee engagement, organizational citizenship behavior, and counterproductive work behavior. International Journal of Business Administration, 4(2).

Arsyad Lincolin. (1999). Ekonomi Pembangunan Edisi Kedua. STIE YKPN, Yogyakarta

Badan Pusat Statistik. (2000-2017) BPS Propinsi Maluku Utara .

Boediono. (1999). Teori pertumbuhan ekonomi. BPFE UGM, Yogyakarta.

Mankiw (1990), Teori Upah Efisiensi. Grafindo, Jakarta

Dewi, S., dan I.B. Purbadharmaja. (2013). Pengaruh PAD, PMA dan Inflasi Terhadap Pertumbuhan Ekonomi Provinsi Bali. E-Jurnal EP UNUD, 2 (11), 502-512.

Dornbusch dan Fischer. (1992). Macroeconomics. Edisi Keempat. Erlangga, Jakarta.

Dumairy. (1997). Perekonomian Indonesia. Erlangga. Jakarta

Ghozali Imam. (2009). Analisis Multivariate Dengan Program SPSS. Badan Penerbit Universitas Diponegoro, Semarang.

Gujarati, Damodar. (2003). Ekonometrika Dasar. Erlangga, Jakarta.
Herman, Emilia. (2011). The Impact of Economic Growth Process on Employment in European Union Countries. The Romanian Economic Journal, Year XIV, No.42.

Handayani, R. (2005). Analisis Faktor-Faktor yang Mempengaruhi Minat Pemanfaatan Sistem Informasi dan Penggunaan Sistem Informasi (Studi Empiris Pada Perusahaan Manufaktur di Bursa Efek Jakarta). Program Pasca Sarjana Universitas Diponegoro.

Hidayat, R. (2010). Keputusan Investasi dan Financial Constraints: Studi Empiris Pada Bursa Efek Indonesia. Bulletin of Monetary Economics and Banking (Buletin Ekonomi Moneter Dan Perbankan).

Indahsari, P. A. N. (2013). Pengaruh Kualitas Pengungkapan Informasi Terhadap Hubungan Antara Penerapan Corporate Governance dengan Kinerja Perusahaan di Bursa Efek Indonesia.

Indra Suhendra, Bayu Hadi Wicaksono. (2016). Tingkat Pendidikan, Upah, Inflasi, Dan Pertumbuhan Ekonomi Terhadap Pengangguran Di Indonesia. Jurnal JEQu Vol. 6, No. 1.

Insukindro. (1993). Uang dan Bank. BPFE UGM, Yogyakarta.

Izhartati. (2017). Pengaruh Investasi Dan Upah Minimum Terhadap Penyerapan Tenaga Kerja Di Kota Bandar Lampung Dalam Perspektif Ekonomi Islam. Fakultas Ekonomi Dan Bisnis Islam Universitas Islam Negeri Raden Intan Lampung.

J Suprianto. (2001). Statistik Teori dan Aplikasi. Erlangga, Jakarta.

Jhingan ML. (2008). Pengantar Ekonomi Edisi Kedua. Erlangga, Jakarta.

Juwita, Y. (2014). Faktor-faktor yang memengaruhi penyerapan tenaga kerja sektor industri pengolahan di Provinsi Jawa Barat (periode 2008-2012).

Kajian Ekonomi Regional Maluku Utara. 20002017. Bank Indonesia

Kotler, P., Kartajaya, H., \& Setiawan, I. (2010). Marketing 3.0: From Products to Customers to the Human Spirit. John Wiley \& Sons.

Lindblad, J. Thomas. 2015. Foreign Direct Investment In Indonesia : Fifty Years Of Discourse. Bulletin Of Indonesian Economic Studies, 51 (2) : 217-273. 
Mankiw,Gregory N. (2000-2003). Teori Makro Ekonomi. Erlangga, Jakarta.

Mudrajad Kuncoro. (2004). Metode Kuantitatif: Teori dan Aplikasi Untuk Bisnis dan Ekonomi. Unit Penerbit dan Percetakan AMP YKPN, Yogyakarta.

Muhammad Nurcholis. (2014). Analisis Pengaruh Pertumbuhan Ekonomi, Upah Minimum Dan Indeks Pembangunan Manusia Terhadap Tingkat Pengangguran Di Provinsi Jawa Timur Tahun 20082014. Jurnal Ekonomi Pembangunan, Vol 12 No.1 Juni 2014.

Nababan, T. S. (2017). The Effects of Number of Industrial Enterprises, Value of Input, Value of Output, And Regional Minimum Wage on Labor Demand in Indonesia: An Empirical Study on Micro Industrial Enterprises.

Ni Wayan Mentari dan I Nyoman Mahaendra Yasa. (2013). Pengaruh Pertumbuhan Ekonomi Dan Tingkat Upah Terhadap Tingkat Pengangguran Melalui Jumlah Investasi Di Provinsi Bali. Fakultas Ekonomi Dan Bisnis Universitas Udayana.

Prayuda, M., dan Urmila Dewi. (2016). Pengaruh Inflasi Dan Investasi Yang Berpengaruh Terhadap Pengangguran Di Provinsi Bali tahun 1994-2013. Jurnal Ekonomi Pembangunan.

Putri, V. K., \& Sasana, H. (2017). Pengaruh Faktor UMK, Belanja Pemerintah Daerah, Investasi Swasta, Serta Inflasi terhadap PDRD dan Posisi Perekonomian Kabupaten/Kota di Provinsi Jawa Tengah Tahun 2010-2015. Fakultas Ekonomika dan Bisnis
Samuelson, Paul A. \& Nordbaus, William D (1996-2004). Mikro Ekonomi. Keempatbelas. Jakarta. Erlangga.

Samuel Randy Tapparan. (2017). Pengaruh Upah Minimum dan Investasi terhadap Kesempatan Kerja di Provinsi Sulawesi Selatan Jurnal Administrare: Jurnal Pemikiran Ilmiah dan Pendidikan Administrasi Perkantoran, Vol. 4, No. 1.

Siregar, H., \& Wahyuniarti, D. (2008). Dampak pertumbuhan ekonomi terhadap penurunan jumlah penduduk miskin. Departemen Pertanian. Jakarta.

Sopianti, K. dan Ketut Ayuningsasi. (2013). Pengaruh Pertumbuhan Ekonomi, Tingkat Inflasi, dan Upah Minimum Terhadap Jumlah Pengangguran Di Bali. Jurnal Ekonomi Pembangunan.

Sukirno, Sadono (2000-2010). Pengantar Teori Ekonomi Makro Edisi Revisi. PT Raja Grafindo, Jakarta.

Sumarlin, Iskandar Syarif, Jhon Tafbu Ritonga, Sirojuzilam. (2010). Analisis Hubungan Tingkat Upah Tinggi Terhadap Produktivitas di Indonesia. Jurnal MEPA Ekonomi USU.

Supranto, J. (2009), Statistik Teori dan Aplikasi, Edisi VII, Erlangga, Jakarta.

Todaro, Michael P. (2003). Pembangunan Ekonomi Dunia Ketiga. Erlangga, Jakarta.

Undang-Undang Republik Indonesia Nomor 13 Tahun 2003 tentang Ketenagakerjaan.

Yeny Dharmayanti. (2011). Analisis Pengaruh PDRB, Upah dan Inflasi Terhadap Pengangguran Terbuka Di Provinsi Jawa Tengah Tahun 1991 - 2009. Fakultas Ekonomi Universitas Diponegoro Semarang. 